\title{
REMOTE EDUCATION IN TIMES OF PANDEMIC: THE EXPERIENCE OF THE COLÉGIO LA SALLE CARMO DE CAXIAS DO SUL/RS
}

http://dx.doi.org/10.5902/2318133867283

\author{
Roberto Carlos Ramos ${ }^{1}$ \\ Marina Camargo Mincato ${ }^{2}$ \\ Kassiana Boeck ${ }^{3}$
}

\begin{abstract}
This text presents an analysis of remote teaching developed by the team of teachers and pedagogical coordination at La Salle Carmo School in Caxias do Sul/RS, during the Covid-19 pandemic, in 2020. The methodology used was a qualitative and exploratory approach, based on a study case. The main results were observed from changes in teachers' thinking, acting and learning throughout the school year. It is concluded that it is possible to maintain a remote and hybrid teaching model - new ways of teaching, management of processes and people, use of active methodologies in remote learning, attractive digital environments - if the school has an available team which is flexible to changes and to work together with students, challenging them to be autonomous and protagonists of a rich and stimulating learning.
\end{abstract}

Keywords: people management; processes; education; remote teaching.

\section{ENSINO REMOTO EM TEMPOS DE PANDEMIA: A EXPERIÊNCIA DO COLÉGIO LA SALLE CARMO DE CAXIAS DO SUL/RS}

\section{Resumo}

Neste texto apresenta-se uma análise do ensino remoto desenvolvido pela equipe de professores e coordenação pedagógica do Colégio La Salle Carmo de Caxias do Sul/RS, durante a pandemia do Covid-19, no ano de 2020. A metodologia utilizada foi a abordagem qualitativa, exploratória, com base num estudo de caso. Os principais resultados foram observados a partir de mudanças no pensar, agir e aprender dos professores ao longo do ano letivo. Concluiu-se que é possível manter um modelo de ensino remoto e híbrido - novas formas de ensinar, gestão de processos e pessoas, uso de metodologias ativas no ensino remoto, ambientes digitais atraentes - se a escola contar com equipe disponível e flexível às mudanças e a trabalhar juntos aos estudantes, desafiando-os a serem autônomos e protagonistas de uma aprendizagem rica e estimulante.

Palavras-chave: gestão de pessoas; processos; educação; ensino remoto.

\footnotetext{
${ }^{1}$ Colégio La Salle Carmo, Brasil. E-mail: roberto.ramos@lasalle.org.br.

2 Colégio La Salle Carmo, Brasil. E-mail: marina.mincato@lasalle.org.br.

3 Colégio La Salle Carmo, Brasil. E-mail: kassiana.boeck@lasalle.org.br.
} 


\section{Introduction}

ovid-19 pandemic, declared by the World Health Organization - WHO - on March 11, 2020, has had an impact on all social segments. In education, as indicated in Report 1, by Carlos Chagas Foundation (2020), "in Brazil, 81.9\% of Basic Education students stopped attending educational institutions. It means a number of about 39 million people" (p. 1).

In this context, the ministry of Education promulgated mechanisms containing standards and measures related to educational activities during a time of pandemic and the proper regulation of the Ministry of Education, allowed the replacement of in-person classes by classes that favor the means and technologies of the information and communication (Brasil, 2020). Therefore, it was possible to continue offering the curriculum in accordance with the school regiment and the political-pedagogical project of the educational institution, associating the remote teaching model, whose production of knowledge, experiences and results contribute to gradually implement the methodological changes and specificities that support this type of teaching.

With remote learning, this educational institution was challenged to reformulate the didactic-pedagogical action, the creation and socialization of virtual knowledge through the content management system on the digital platform Google Classroom, websites and learning devices. These were some of the strategies adopted with the 1,840 students who had access to technology and the internet. Associated with this management system, the educators adopted technological tools and resources which considered appropriate for the development of competences prescribed in Study Plans.

In this context, "video classes, virtual meetings, lives, drives, virtual correction, class scheduling [...] are terms that have come to embrace the everyday life of the 21 st century educator, previously used sparingly, almost imperceptibly" (Monteiro, 2020, p. 18), as well as teacher training and monitoring aiming the development of skills in virtual environments, by the pedagogical staff.

Tied to this diversity and sudden change in face of the impossibility of conducting inperson classes, the remote teaching-learning process became a reality and the feeling was the existence of "a restlessness in the air. We have the feeling of being on the edge of time, between a present about to end in a future that has not been born yet" (Souza, 2005).

This new educational reality, which emerged as a result of circumstances of a time of pandemic, has derived a profound challenge for education professionals. According to Larrosa; Sklir (2001), we are living with technological development, being too much valuable. In-person classes turned into remote classes overnight, and most educational institutions chose to maintain their teaching activities, challenging to "adapt, temporarily, from in-person teaching to remote learning" (Rodrigues, 2017, p. 27).

The viability of remote teaching was based on educational experiences of educators, associated with daily learning, when continuous improvements were made in remote teaching and training, ensuring the development of scientific knowledge, in order to contribute and ensure the quality of education in times of pandemic.

Autonomy, involvement, teamwork, people management and processes are concepts present in this journey, with an emphasis on organizational learning and on the development of people who are committed to strategic issues related to specific tasks in 
different areas of knowledge and in the virtual learning environment. The contents, skills and management of people to learn collectively, the information used in the decisionmaking process, the talent and availability of educators, the network of contacts, teamwork, in short, a large category of assets are considered substantial elements for the development of remote learning.

This educational scenario motivates this study, for which it was tried to make use of this experience in the eagerness to know the processes in strategic management of people and innovation that contributed to remote learning at La Salle Carmo School in times of social distance, caused by Covid- 19 .

The research, study type, focuses to analyze the remote teaching developed by the staff of pedagogical coordination and educators, from the perspective of people and processes management, developed at La Salle Carmo School, in the city of Caxias do Sul/RS, during the pandemic of Covid-19, in 2020.

The text is divided into four sections, being this the first. Next, on the theoretical foundation, we rely basically on carefully selected theorists, focusing on the strategic management of people and processes. The third section comprises the methodology used in the research. The fourth section concerns the results and conclusion obtained with remote learning, regarding the processes followed, the activities implemented and the experiences of the goals, enhancing the learning of this new practice and adherence to the method developed by educators in their subjects.

\section{Strategic people management}

Anyone, even the most layman on the subject, would say if institutions are made up of people, their role is decisive in any circumstance. Therefore, they are strategically essential in teaching-learning.

In this new educational background, the strategic management of people implies the ability to understand the relationship between the external environment and the institution, as well as to analyze the internal capabilities of that institution. One of the critical factors in this process refers to the strategic management of knowledge, whose main levers are knowledge production, new encouragement for learning and educators' creativity. (Oliveira, 2015).

Remote learning has required from educators a posture focused on selfdevelopment, physical and mental health care, continuous learning, especially with new information and knowledge technologies, creativity in classes, and the ability to deal with information, a reality of social isolation, transforming them into knowledge. For Éboli (2002), these trends point to a new aspect in the establishment of sustainable advantages, which is the educational institution's commitment to education and people's development.

According to the author (Éboli, 2002), for an education system or a pedagogical project to achieve its purposes, it is necessary the involvement and commitment of people, motivated to create a simple and effective education system, with a culture of principles and values that lead to new learning processes. Towards that, it is necessary to favor the development of competences, attitudes, skills and knowledge, together with educators, that guarantee home educational processes and that adopt new technological and methodological elements of teaching-learning in order to promote the change of a passive role, to an active role of educators.

Regae: Rev. Gest. Aval. Educ. $\quad$ Santa Maria

v. 10

ก. 19

e67823, p. 1-13

2021 
In this regard, teacher training "is important in institutions, however, most of the time, it is used more as a tactical and operational approach, and its programs are not aligned with the organization's strategy" (Oliveira, 2015, p. 7).

According to Rhinow (2001), the valuation of learning stems from the awareness of the educational institution and educators about a statement capable of generating insights into their strategic actions. The ability to constantly learn tends to be the only sustainable and qualifying advantage for institutions at the current time. A finding which becomes valuable in today's world of very innovative education.

By training challenging the new and saying that the educator is competent for a certain aspect, it is said that he or she is able to assimilate what is happening and making decisions in the face of a pandemic scenario. Therefore, when working on strategic people management, there is a vision of the whole and the goal is known. In other words, the management team and the pedagogical coordination, adopting new remote pedagogical models at such a challenging time for education "is to face the educational institution horizontally, where skills and lack of competence become evident, so that investments can and should be made permanently and punctually" (Araújo; Garcia; Martines, 2011, p. 45).

Such statements feed the pedagogical practice of remote education, in which it is possible to identify, in several stages, "mentions to the concept of learning in the strategic guidelines, as contents and actions in its vision and mission" (Rhinow, 2001, p. 4). For the author, the need for organizational learning is evident. The focus of strategic people management is directly aimed at educators, considered sources and mediators of students' teaching-learning processes in school organizations. Thus, people appear as a highly relevant factor for the development of remote learning. Consequently, the permanent challenge of the management and pedagogical team is to carefully manage this teaching model, especially in the process of mediation, pedagogical monitoring, motivation, resilience and several issues that arise.

According to Borges (2006), human learning happens in different ways and there are several concepts which involve the actions that lead to learning: training and development in education. Given the needs of modern societies, it is not possible to define education regarding a particular period of life. The educator needs to learn throughout life (Unesco, 2015), and remote learning has enabled one of these learnings, which very effectively shape the development of people, creating conditions so that demands emerge for the benefit of development of educators, students and the educational institution (Rhinow, 2001).

The tools and virtual environments, used to teach remote classes, bring another great benefit: they create effective conditions for identification through the development of skills for professionals. The systematic exercise of assessment, in terms of different dimensions of those involved, including family members, students and civil society, leads to a consistent perception of the set of knowledge, skills and attitudes that need to be developed during the process.

Facing the contingencies of educational and social scenario in times of pandemic, the actions implemented by the project arise due to the urgent need for new educational responses and complex demands of society, verified by the educators themselves. In view of these challenges, some points should be highlighted regarding the effectiveness of education. First, failure of the cognitive model used by lectures and readings, whether in 
the classroom or even in virtual environments, as the only form apparently used by educators. From this reality of traditional education, remote teaching emerges from the urgent need for ongoing training of educators in the areas of new technologies, hybrid teaching and the opportunity to use new teaching methods and didactics, aiming at learning new knowledge, improving skills and the amendment of professional attitudes (Rhinow, 2001).

This paradigm shift ended up being strategically implemented by people through their practices, training and development of skills required by remote education, which required motivation, skill, creativity, overcoming limits, recreating educational values, emotional balance, human interaction, resilience, identification and effective management of the identified challenges. Furthermore, the success of these educators increasingly depends on the opportunity to learn and experiment with new skills and knowledge. Therefore, the educational institution needs to continually invest in the development of its educators, through continuing education and institutional learning.

\section{Process management}

In remote education, it was necessary to think of constructive processes that would contribute so that education and those involved took significant steps towards the transformation of the new teaching model, in a creative and innovative way, and about school organization.

Thinking, acting and learning are essential for the management of the process instituted by remote education, based on the experience of joint construction. Understanding the context in which we lived, the mentality of educators, the new proposal for remote teaching and the motivation of the directive and pedagogical team was essential for defining the teaching plan, planning classes and teaching activities to be carried out based on this way of teaching.

Understanding the homeschooling proposal was the first step: "Consider how understanding and the ability to visualize form and processes are organized and designed" (Paim et al, 2009, p. 162). In this context, from the initial moment we are faced with home education, opening to new processes and action on the new teaching proposal, different from the one experienced by everyone then, and the idea of building together this teaching model, with the on monitoring teachers and students, it involved "the performance of tasks that respond to the concepts accompanied by the internal and external environment, the selection, modeling, improvement, implementation and management of knowledge and changes in processes" (Paim, et al, 2009, p. 146).

In order to implement and achieve new educational processes in this context it was necessary,

understand the external and internal environment and organizational strategy; set goals and approach to promote changes; ensure sponsorship for change; understand, select and highlight improvement processes, tools and techniques, understand the process in the current situation; define and prioritize solutions to problems; define project management, practices and changes to new processes; implement new processes. (Paim et al, 2009, p. 146) 
The tasks to manage processes and people on a daily basis are associated with concepts of enabling the enforcement and carrying out of slow and resistant processes, with monitoring, adjustments and small changes in the short term in home office work, with the challenge of building new concepts and educational plans, which were subsequently assumed by educators, with the proposal to challenge change, built through online meetings, frequent and permanent digital contacts with the entire pedagogical staff.

Training around new educational technologies and technological support was the "promotion of learning and day-to-day management of processes" (Paim et al, 2009, p. 147), where concomitantly, with daily practice, educators and the pedagogical team challenged each other and contributed to understanding, learning, teaching and evaluating the personal followed journey with the aim of better performing the proposal of home education.

Thinking about the remote learning model allowed "composing the notion that the process manager must always design the processes" (Paim et al, 2009, p. 147). Face-toface teaching was centered on a traditional model, with defined processes, strategic direction for the use of legitimized techniques and didactics, qualitative and quantitative definition of the rooted and systematic problems faced. Remote education promoted and fostered a new way of thinking, providing education and acting as an educator, which the social context was demanding (Paim et al, 2009).

According to this background, thinking was centered on a strategy of remodeling the teaching-learning process, human relationships online and educational practices, taking advantage of the several tools of digital platforms, in order to achieve educational quality that fosters change in the local community and in the lives of educators. The improvement of remote learning processes fostered reflection on the importance of managing change, always understanding and respecting the context in which we live, interactions, culture and the educational environment.

Acting was linked to the management of processes on a daily basis, with planning and concrete actions. These processes promoted the expected functioning so that the work and the way of being and acting of those involved took place in an adequate way to what was studied and planned (Paim et al, 2009).

In this process, the challenge of educators and pedagogical coordination is to manage and deal with the educational plan built and rebuilt weekly, acting according to demands, monitoring and making the pre-established happen. This aim was sometimes not so simple, it generated anxiety, insecurity, pressure and demands from the families, as the mental change of everyone was not fully integrated and synchronized, that is, everyone had in mind the face-to-face teaching model. Little by little, it was implemented as we had planned, always bearing in mind the quality of home education.

"Learning was the promotion of learning about this entire process" (Paim et al, 2009, p. 217). Monitoring, training and drastic and progressive changes in this teaching model have been strengthened over the period. Learning, organizational and personal growth were associated with collective creation and construction, receptiveness to ongoing training and daily monitoring of processes. Furthermore, they were also linked to the records of their performance and evolution, to the contents studied, to the history of educators' performance in interpersonal relationships with students as well as the improvement of performance in their educational practices (Paim et al, 2009).

\begin{tabular}{|l|l|l|l|l|l|}
\hline Regae: Rev. Gest. Aval. Educ. & Santa Maria & v. 10 & n. 19 & e67823, p. 1-13 & 2021 \\
\hline
\end{tabular}


Regarding to educators who build processes, it is clear that in any environment,

organizations are formed by people, their role in any circumstance is decisive. However, "decisive" is a somewhat comprehensive classification, which does not help much to make decisions, especially regarding the processes that take place there. (Araújo; Garcia; Martines, 2011, p. 117)

At La Salle Carmo School, the decision to change should come from the management staff and the pedagogical coordination, essentially followed by the educators, as they are the main responsible for the change process. The main challenge found in this new educational process, fostered by remote learning, was directly related to the process that people should do in order to achieve the set goals.

According to Araújo; Garcia; Martines (2011), people are essential to achieve the proposed goals. It is extremely important to develop competence, leadership and the culture of a new way of teaching. The competence "can and must be achieved". Leadership "cannot be imposed". Culture "needs to be worked towards a proposal every day, being this a management of processes and people or not".

This new process required from managers the ability to accept sudden change, to take new attitudes, as well as understanding people and processes and finally interpersonal relationships between educators and students. Leaving the common sense of everyday educational life and undoing the face-to-face teaching model was essential to achieve excellence in remote education, ensuring the principles of the school.

The insertion of remote learning instituted new processes and changes in educational practice: "Promoting operation involves making the work happen properly, or as expected and designed" (Paim, et al, 2009, p. 208). To this end, the role of educators is to manage or deal with the flow of study objects and the action of home education. Basically, making the 'stick to be transferred' throughout the stages of the process in the day-to-day of classes, for the commitment of students to be connected to classes and to be protagonists in the teaching-learning process.

These objects, or stick, "are often information, materials, search for resources, people, ideas, knowledge that, in many situations, must go together, in an articulated, synchronized, integrated and coordinated manner" (Paim et al, 2009, p. 208).

The process definitions already represented allow us to understand that process management must also be carried out on a daily basis. The practices defined in the educational plan are essential and necessary from planning to practice. Allocating resources to tasks, supervising progress, and controlling results can all be summarized as getting process activities carried out (Paim et al, 2009).

The task of implementing remote learning, promoting the achievement of processes involving planning, programming, creativity, innovation and action are essential for shortterm changes, not declining the importance of satisfactory internal communication and among the several stages of activities, as well as with the families of the students.

Change management was an integral part of this teaching change, implementing structural, strategic and mental changes. The biggest challenge, however, was to engage educators to make them cooperate with the implementation of new processes and be efficient in the changes that occurred in the educational journey. 
Changing is not simple and, most times, it is not easy, especially when it comes to changing the face-to-face model of education to a totally remote one. Therefore, the opportunity offered to train educators, especially on the technological resources of education, is fundamental, as it is closely linked to change management. And it occurs through the implementation of new educational practice and change of attitudes towards students, mainly (Lopes; Stadler; Kovaleski, 2014):

A change takes people out of their comfort zone and take them into the unknown. It is normal to be afraid of what you do not know. In this aspect, the change leader has the basic functions of explaining as much as possible where he wants to go and highlighting the opportunities of the new situation, minimizing resistance. People only change and accept change when they trust and follow the leader of the change process. Imposed changes tend to fail over a short period of time. (p. 56)

In addition to managing everyday issues, which was relevant, the focus was also on "finding new paths for change procedures when we have conditions, better, when we have the means and ways, or when we are able to fight and achieve these means" (Araújo; Garcia; Martines, 2011, p. 129).

\section{Processes and people management in the implementation and improvement of remote learning}

In this context, the protagonists for the implementation of remote learning were the educators, because overnight, in a matter of 3 days, classes moved from face-to-face to remote teaching and had a whirlwind of demands to be met, such as: reorganizing routines personal and family, and in many cases, totally changed, to improve and revise the plans in view of the sudden change in the way of educating, meeting the legal demands proposed by the government, access to infrastructure such as internet, computer and learning platforms, mastering new teaching tools, methodology and ensuring student learning, developing new skills and experiences based on personal and institutional values, learning and innovation skills, the paradigm shift in teaching, training and education aiming to guarantee the mastery of new communication and information technologies.

In the processes of implementation and improvement of remote learning, they followed these paths:

a) The first moment, in the initial phase of the pandemic, remote learning took place on an emergency basis, in which teaching material and exercises were made available through the partner publisher's platform, which allows parents and students access to academic information, in order to ensure the continuity of teaching.

At this stage, process management also facilitated the basic paths of teacher instruction and planning, all created according to the moment experienced, highlighting the daily and weekly remote teaching lesson plan according to each subject, guaranteeing an integrated curriculum between subjects, replacement of classes according to the school calendar. The organization of classes, respecting the quarters term plan considered the 
contents, skills and competences, obviously already established by the educators in the face-to-face period, rethinking the procedural aspects so that everyone could perform it remotely, without face-to-face mediation of the educator and, above all, without distancing himself from what was planned.

In this scenario, the pedagogical team was challenged to remain calm and avoid possible panic among educators, students and family members in view of the new challenge, following the unfolding of the pandemic and the rules of the State of Rio Grande do Sul.

b) The second moment took place after a month without in-person classes. With the increase of social distancing, indicated by municipal and state decrees, a virtual classroom, or virtual learning environment, was created at all levels of education, on Google for Education platform, using tools such as Google Classroom.

In this adopted scenario, according to a systematized calendar, students had classes on average twice a day. And again, the educators were challenged to plan and execute their classes in a mixed way, which allowed a closer relationship between students and educators, and the activities started to be posted in the same rooms. At the same time, educators, pedagogical staff and information technology held the online course and training through lives on YouTube through Google for Education, in addition to motivational lectures via Hangouts Meet.

c) The third occurred at the beginning of the third stage of home teaching, when each class had its own virtual classroom, with online classes in the classroom according to the weekly timetable of in-person classes, requiring a pedagogical dynamism of all educators, in order to provide interaction, participation, permanence and well-being of students in virtual classrooms, with proper monitoring and adjustments by the pedagogical team and information technology department.

d) The fourth moment consisted in the return of classes with the presence of $50 \%$ of students from each classroom and the others online on the learning platform, interspersing the days, simultaneously integrating classroom and online classes, requiring a new model and processes from everyone of communication, which made it possible to know and discuss different realities of the world, bringing to light those of models and hybrid teaching methods.

In this last moment, already stable, many methodological and didactic actions were carried out by the educators and with more propriety and confidence to teach remote classes, diagnosing the profile and mood of each class, as well as evaluating the individual and collective educational process. It is important that before starting each class or at the beginning of the week, the teachers' challenge was to check-in, feel and listen to the moment when students presented their interests, anxieties, learning, motivations and desires to perform and participate in the remote classes. At the end of the class week, there was a check-out moment, by which students presented the challenges, opportunities, difficulties and learning at a personal and group level. 


\section{Evolution of people management processes in this educational practice}

Formal education is facing an impasse in face of so many changes caused by the pandemic: how to evolve to become relevant and get everyone to learn, in a competent way, to live, know and build this teaching model. Notably, the processes involving curriculum organization, methodologies, time and spaces have evolved significantly.

The standardized and traditional school, which teaches and evaluates everyone equally and requires predictable results, through the remote learning model, evidence knowledge based on competences, skills, attitudes and that require proactivity, collaboration, personalization and entrepreneurial vision of educators and pedagogical coordination, eliminating the certainties of the educational journey.

Remote learning emerges as an evolution of this traditional education, integrating people's processes within their home spaces and times of social isolation. Teaching and learning take place in a symbiotic, deep, constant interconnection between what we call the physical world and the digital world. They are not two worlds or spaces, but an extended space, an extended classroom, which mixes and constantly hybridizes. That is why formal education is increasingly blended, mixed, hybrid, because it does not happen only in the physical space of the classroom, but in multiple virtual spaces. The educator needs to keep communicating face to face with students, even if virtual, but also balancing educational processes, integrating with everyone.

Remote learning was a challenge and demanded immediate responses from everyone, and the virtual learning environment was essential to open the school to the world and to bring the world into the school. Another mix was to provide for more planned, organized and wider formal communication processes, such as those that happen on social networks, where there is a more familiar language, greater spontaneity, a constant fluency of images, ideas and videos, optimizing learning.

During the learning process, different action plans were used as well as learning tools, to operationalize home teaching, which always started from an experience based on reality. Another differential was mentoring as a break in educational paradigms, which helped in self-development. Adding to this whole process co-creation, collaboration and sharing were always present in the teaching-learning process, in the solutions to problems that emerged, in the daily experiences, resources and teaching methodology. Educators and pedagogical coordinators took turns in these roles and, when necessary, invited other professionals to share their experiences and wisdom in remote classes.

Remote learning contributes to an education based on the experience/meaning pair, built by uniting people management and educational processes. As for meaning, it explores it from the subject of experience, defined not by its activity, but by the opening to be transformed by experience - territory of passage, submitted to a logic of passion. The knowledge of experience arises from the relationship between knowledge and human relationships, singular and concrete.

Those involved appropriated multiple skills and experience with this teaching model. It was much more than a laboratory to create new methodologies and educational processes, as it provided the development of new skills, learning, time and change management, it qualified interpersonal and professional relationships as a result of people management processes. 


\section{Final considerations}

Finally, it is possible to keep a remote and hybrid teaching model - new ways of teaching, management of processes and people, new and active methodologies, attractive digital environments - if the school has educators who are available and flexible to change and work together with students, challenging to be autonomous and protagonists of a rich and stimulating learning.

It is known that in this social and educational context the biggest challenge is to foster the people management process. In order to achieve the best results, without a doubt, it is necessary to be prepared and open to the surprises that the world offers us, which have required from people and professionals the ability to face complex choices, capable of undertaking, creating and living in scenarios of instantaneous change.

In order to implemented home education have an effect towards the intention for which it was defined and chosen, it was necessary that educators of this process assimilated it, in order to understand and believe in its pedagogical and innovative potential, and imprinting a good dose of intellectual (studies) and affective (virtual interpersonal relationships) availability to work according to the proposal, since there are many conditions in the school and social context that could even impede the implementation of remote learning.

The management of processes and people, from this perspective, has a significant relevance as commitments, responsibilities and the promotion of ongoing training are added. The interaction between the pedagogical team and educators was one of the main sources for the execution and evolution of the educational processes and the motivational quality of the project and those involved in it.

Therefore, an interesting challenge for future research is the record of the ways in which the experiences of managing people and processes aimed at teachers are carried out, with new educational methodologies and their effects on students, in order to broaden reflections and evidence of its pedagogical and learning benefits in the global context.

\section{Bibliography}

ANDRÉ, Marli. Estudo de caso em pesquisa e avaliação educacional. Brasília: Liber Livro, 2005.

ARAUJO, Luís Cesar G. de; GARCIA, Adriana Amadeu; MARTINES, Simone. Gestão de processos. São Paulo: Atlas, 2011.

BACICH, Lilian; TANZI NETO, Adolfo. TREVISANI, Fernando de Mello. Ensino híbrido: personalização e tecnologia na educação. Porto Alegre: Penso, 2015.

BORGES, Andrade. Treinamento, desenvolvimento e educação em organizações e trabalho. Porto Alegre: Artmed, 2006.

BRASIL. Portaria n. 343, de 17 de março de 2020: dispõe sobre a substituição das aulas presenciais por aulas em meios digitais enquanto durar a situação de pandemia do Novo Coronavírus - Covid-19. Published on: 18/03/2020, edition: 53, section: 1, page: 39. Available at: http://www.in.gov.br/en/web/dou/-/portaria-n-343-de-17-de-marco-de-2020248564376. Access on $1^{\circ}$ jul. 2020.

DESLAURIERS, Jean-Pierre. Recherche qualitative: guide pratique. McGraw-hill, 1991. 
ÉBOLI. Marisa. O desenvolvimento das pessoas e a educação corporativa. São Paulo: Gente, 2002.

GIL, Antonio C. Como elaborar projetos de pesquisa. São Paulo: Atlas, 2008.

LARROSA, Jorge; SKILIAR, Carlos. Habitantes de babel: política e poética da diferença. Belo Horizonte: Autêntica, 2001.

LOPES, Paulo Cesar Barbosa; STADLER, Carlos Cesar; KOVALESKI, João Luiz. Gestão da mudança organizacional. Revista de Ciências Humanas, Ciências Sociais Aplicadas, Lingüistica, Letras e Artes, Ponta Grossa, v. 11, n. 1. 2003, p. 51-57.

LÜDKE, Menga; ANDRÉ, Marli. Pesquisa em educação: abordagens qualitativas. São Paulo: EPU, 1986.

OLIVEIRA, Elaine Lima de. Educação corporativa: uma estratégia na gestão de pessoas em instituição de ensino. Available at: https://convibra.org/publicacao/1724/. Access on 10 ago. 2021.

UNESCO. Marco de ação: educação 2030: rumo a uma educação de qualidade inclusiva e à educação ao longo da vida para todos. Brasília: Unesco, 2015.

PAIM, Rafael et al. Gestão de processos: pensar, agir e aprender. Porto Alegre: Bookman, 2009.

RHINOW, Guilherme. Inovando e competindo por meio de gestão de pessoas. Revista de Administração de Empresas, São Paulo. v. 8, n. 1. 2001, p. 2-7.

SOBOLL, Lis Andrea; FERRAZ, Deise Luiza da Silva (org.). Gestão de pessoas: armadilhas da organização do trabalho. São Paulo: Atlas, 2014.

SOUZA, Rosa Fátima de. Tecnologias de ordenação escolar no século XIX: currículo e método intuitivo nas escolas primárias norte-americanas (1860-1880). Revista Brasileira de História da Educação, São Paulo, n. 9, 2005, p. 9-42.

TRIVIÑOS, A.N.S. Introdução à pesquisa em ciências sociais: a pesquisa qualitativa em educação. São Paulo: Atlas, 1987.

YIN, Robert. Estudo de caso: planejamento e métodos. Porto Alegre: Bookman, 2005.

Roberto Carlos Ramos é diretor do Colégio La Salle Carmo de Caxias do Sul/RS.

Orcid: https://orcid.org/0000-0002-3972-7528.

Endereço: Rua Os Dezoito do Forte, 1754 - 95020-472 - Caxias do Sul - RS - Brasil.

E-mail: roberto.ramos@lasalle.org.br.

Marina Camargo Mincato é coordenadora pedagógica do programa bilíngue e professora da Língua Inglesa do Colégio La Salle Carmo, Caxias do Sul/RS.

Orcid: https://orcid.org/0000-0002-6280-6435.

Endereço: Rua Os Dezoito do Forte, 1754 - 95020-472 - Caxias do Sul - RS - Brasil.

E-mail: marina.mincato@lasalle.org.br. 
Kassiane Boeck é orientadora educacional e psicóloga do Colégio La Salle Carmo, de Caxias do Sul/RS.

Orcid: https://orcid.org/0000-0001-7578-8355.

Endereço: Rua Os Dezoito do Forte, 1754 - 95020-472 - Caxias do Sul - RS - Brasil.

E-mail: kassiana.boeck@lasalle.org.br.

Critérios de autoria: os autores atuam profissionalmente no mesmo ambiente educacional. Vivenciaram juntos a experiência de gestão de pessoas e processos. Realizaram coletivamente a concepção, criação, redação, análise de dados, consolidação e conclusão do artigo. Roberto, Marina e Kassiane foram responsáveis pela descrição do relato de experiência e coleta dos dados. Roberto Carlos Ramos foi responsável pela fundamentação teórica referente aos marcos reguladores da educação brasileira, gestão de processos e metodologia. Kassiane foi responsável pela fundamentação teórica de gestão de pessoas. Marina foi responsável pela correção ortográfica e gramatical, assim como a tradução para o inglês.

Recebido em 19 de agosto de 2021.

Aceito em 25 de outubro de 2021. 